УAK 347.764:796.071.2(477)

DOI https://doi.org/10.32837/chc.v0i38.367

Токарева Віра Олександрівна,

канАиАат юриАичних наук, Аоцент кафедри цивільного права

Національного університету "ОАеська юридична академія" ORCID https://orcid.org/0000-0002-8409-1477

\title{
ПРАВОВЕ РЕГУЛЮВАННЯ СТРАХУВАННЯ СПОРТСМЕНІВ
}

Постановка проблеми. Професійний спорт асоціюється не лише з успіхом, рекордами та Аосягненнями, а й високим ризиком Аля зАоров'я. ПіА час навчально-тренувальних занять або спортивних заходів існує висока ймовірність настання нещасних випаАків та травмування, Ао того ж професійна спортивна Аіяльність із метою Аосягнення результату пов'язана з високим фізичним та психологічним навантаженням.

Статистика професійних захворювань та травм сереА спортсменів не ведеться, що створює склаАнощі Аля визначення, кількості спортсменів, які отримали страхові виплати і які випаАки віАбуваються найчастіше [1].

Актуалізується необхіАність належного захисту спортсменів вищих Аосягнень, і перш за все професійних спортсменів віА негативних зовнішніх факторів. Охорона спорту в цілому повинна бути спрямована перш за все на охорону зАоров'я спортсменів, юридичний захист на випадок втрати працездатності внаслідок травми, захист їх віАповіАних прав при укладенні та виконанні спортивних контрактів тощо. Разом із тим неріАко контракти у сфері професійної спортивної Аіяльності характеризуються слабкою економічною та правовою захищеністю спортсменів [2].

Тому в галузі сучасного спорту, з високими швиАкостями, конкуренцією, ймовірністю настання травм та віАміни змагань, постає потреба застосування заходів Аля покриття раптово виникаючих випаАків, якими покликано стати саме страхування.

Метою статті $€$ аналіз та огляА окремих питань правового регулювання страхування спортсменів, встановлення прогалин та розробка пропозицій Аля вАосконалення законодавства в зазначеній сфері.
ВикиаА основного матеріалу. Страхування $€$ виАом цивільно-правових віАносин щодо захисту майнових інтересів фізичних осіб та юридичних осіб у разі настання певних подій (страхових випадків), визначених Аоговором страхування або чинним законодавством, за рахунок грошових фонаів, що формуються шляхом сплати фізичними особами та юридичними особами страхових платежів (страхових внесків, страхових премій) та доходів віА розміщення коштів цих фонАів (ст. 1 Закону України «Про страхування»).

Страхування в галузі спорту включає такі різновиди ризиків, пов'язаних із організацією спортивних заходів:

- страхування віА нещасних випадків та медичне страхування спортсменів;

- страхування особистого майна спортсменів, спортивного інвентарю й обладнання команА віА вогню, псування водою та крадіжки;

- цивільна відповідальність організаторів спортивних змагань або учасників спортивних правовіАносин (гравців, судаів, тренерів, вболівальників тощо) переА третіми особами на випадок смерті, каліцтва чи іншого ушкодження зАоров'я, повної або часткової втрати працездатності третіх осіб з вини організаторів змагань, а так само у зв'язку зі знищенням або пошкодженням майна при проведенні змагань з вини організаторів;

- страхування на випадок скасування, віАстрочення, перенесення спортивних заходів з причин, що не залежать віА учасників та організаторів змагань [3].

Ао того ж страхування в галузі спорту може містити властивості реклами та піару. Так, у 2006 році АевіА Бекхем застрахував зАоров'я на 
суму 100 млн. фунтів (приблизно 180 млн. Аоларів), що стало найдорожчим страховим покриттям в історії спорту. Страхове покриття охоплювало травми, естетичні дефекти, захворювання, отриманні футболістом на полі, та частково витрати ФК Реала, у разі втрати гравця. Через значний розмір страхової суми, віАповіАно високого тарифу та страхового платежу у його виплаті взяли участь компанії Motorola та Pepsi, в рекламі яких брав участь спортсмен.

ВіАповіАно Ао заяви представника клубу Real Madrid ноги Кріштіано Роналдо застраховані на 144 мільйонів доларів [4].

Застраховані великі пальці рук гонщика команди Формули-1, Фернандо А^онсо, виступаючого за Ferrari. Аоговір передбачає виплату страхового віАшкодування у розмірі 10 мільйонів євро у разі настання нещасного випадку з пальцями іспанського гонщика.

Щодо страхування спортсменів віА нещасних випадків, то Ааному виду страхування властива реалізація таких ризиків:

1) Травми, отримані на шляху проходження на спортивні заходи і назал на транспортних засобах;

2) аварії безпосередньо під час навчально-тренувальних процесів або проведення спортивних змагань;

3) нещасні випадки через нанесення тілесних ушкоАжень іншою особою,

4) навмисне вбивство піА час участі у спортивному заході;

5) ушкоАження зАоров'я піА час стихійного лиха (землетрус, ураження блискавкою, зсуви, селі, повені, урагани та ін.);

6) травми, теплові удари, опіки, пошкодження в результаті контакту із тваринами і комахами і тощо.

ВіАповіАно Ао ст. 5 Закону України «Про страхування" страхування може бути провадитися в добровільній або обов'язковій формі.

Аобровільне страхування передбачає, що всі істотні моменти Аоговору страхування визначаються виключно за згоАою сторін.

Згідно із законом України "Про страхування" форми типового Аоговору і порядок проведення обов'язкового страхування визначаються Кабінетом Міністрів України.

ВіАповіАно до п. 1 ст. 7 Закону України «Про страхування" та ст. 43 Закону України "Про фізичну культуру та спорт" [5] спортсмени вищої категорії піАлягають обов'язковому страхуванню, яке зАійснюється згіАно з ПоряАком та умовами обов'язкового Аержавного страхування спортс- менів вищих категорій, затверАжених Постановою Кабінету міністрів України віА 31 травня 1995 № 378 [6] (Аалі ПоряАок).

Таким чином, піА час укладання Аоговору обов'язкового страхування спортсменів вищих категорій ні у страховика, ні у страхувальника практично не лишається свободи маневру, аАже всі суттєві моменти будь-якого виАу обов'язкового страхування, навіть сама форма Аоговору, заздалегідь визначені законодавчими актами [7].

Спортсменами вищих категорій визнаються спортсмени, які мають найвищі Аосягнення на офіційних національних та міжнародних змаганнях і які включені згіАно зі спортивним рейтингом Ао складу збірних команА України (ст. 1 Закон України «Про піАтримку олімпійського, паралімпійського руху та спорту вищих Аосягнень в Україні” [8]).

ВіАповіАно ао Поряаку обов'язковому Аержавному страхуванню піАлягають спортсмени збірних команд України, яке здійснюється за рахунок коштів державного бюАжету, що виАіляються на утримання штатних збірних команА України. Обов'язкове державне страхування спортсменів збірних команА України зАійснюється на випаАок: загибелі або смерті застрахованого піА час піАготовки Ао змагань та участі в них; втрати застрахованим працездатності внасліАок поранення, контузії, травми або каліцтва, захворювання чи інваліАності, що сталися піА час піАготовки до змагань та участі в них.

ЗгіАно зі ст. 3 Закону України "Про піАтримку олімпійського, паралімпійського руху та спорту вищих досягнень в Україні" Аержава забезпечує соціальний захист членів збірних команА України з олімпійських та паралімпійських виАів спорту шляхом фінансування витрат на обов'язкове Аержавне та медичне страхування спортсменів вищих категорій.

Страхування професійних спортсменів Аає можливість отримання першої медичної Аопомоги у випадку настання травми, яку оплачує страхова компанія, та:

1) оплати медичних заходів, включаючи діагностику, операцію, лікування в стаціонарі;

2) оплати мікарських препаратів і необхідних засобів або пристосувань;

3) оплати реабілітаційного періоду.

Страхувальниками визнаються юридичні особи та дієздатні фізичні особи, які уклали зі страховиками Аоговори страхування або є страхувальниками віАповіАно до законодавства України. Законодавство уповноважує страхувальників 
укладати зі страховиками Аоговори про страхування третіх осіб (застрахованих осіб) ^ише за їхньою згодою, крім випадків, передбачених чинним законодавством (ст. 3 Закону України «Про страхування").

ВіАповіАно до Порядку страхувальником за Аоговором обов'язкового Аержавного страхування спортсменів вищих категорій може виступати Міністерство молоді і спорту України, Міністерство оборони, МВС, Служба безпеки України.

Страховики є професійними учасниками страховихправовідносин. ВіАповіАнодоч. 1ст. 2Закону України "Про страхування" страховиками визнаються фінансові установи, які створені у формі акціонерних, повних, командитних товариств або товариств із Аодатковою відповідальністю, які одержали у встановленому порядку ліцензію на зАійснення страхової Аіяльності. Учасників страховика повинно бути не менше трьох. Загальні умови та порядок зАійснення страхування спортсменів вищих категорій визначаються правилами страхування, що встановлюються страховиком самостійно відповіАно Ао вимог Закону України "Про страхування" та піАлягає затвердженню уповноваженим органом.

Застрахованими є спортсмени збірних команА України, що готуються до участі у спортивних змаганнях чи беруть участь в них.

Страхувальники вносять страхові платежі Ао 25 числа кожного місяця в розмірі 5 відсотків фонау оплати праці, вк^ючаючи встановлені чинним законодавством Аоплати та надбавки застрахованим за минулий місяць. Облік надхоАжень страхових платежів і виплат страхових сум із зазначеного виду страхування повинен вестися окремо віА надходжень і виплат за іншими видами страхування. Витрати страховика на здійснення страхування не повинні перевищувати 6 відсотків страхових платежів. Страхова сума дорівнює Аесятирічному утриманню спортсмена за його останньою посадою.

Страховик здійснює виплату страхової суми в разі настання таких випаАків (віАповіАно Ао п. 4 Поряаку):

1) загибелі або смерті застрахованого піА час підготовки Ао змагань та участі в них - його спадкоємцям, у розмірі десятирічного грошового утримання застрахованого за останньою посаАою, яку він займав;

2) втрати застрахованим працездатності внас^ідок поранення, контузії, травми або каліцтва, що сталися піА час піАготовки Ао змагань та участі в них, - у розмірі, який визначається з роз- рахунку середньої заробітної плати пропорційно терміну втрати працездатності, встановленому медичним закладом, за умови, що ушкодження зАоров'я застрахованого віАнесено Ао категорії тяжких травм згінно з медичною класифікацією травм, затвердженою М03;

3) установлення застрахованому інвалінності в період чинності Аоговору страхування, Ао якої призвів нещасний випаАок, що стався піА час підготовки Ао змагань або участі в них: І групи 100 відсотків страхової суми; І групи - 80 відсотків страхової суми; III групи - 60 відсотків страхової суми.

ПіА час страхування спортсменів виділяють групи ризиків залежно віА виду спорту, небезпечності травм та ймовірності настання випадку, що впливає на розмір страхового тарифу віА нещасних випадків і медичного страхування спортсменів. Виділяють такі групи ризиків:

- Ауже високі ризики - до них належать екстремальні види спорту (Аельтапланеризм, альпінізм, скелелазіння, підводні та підземні види спорту, стрибки з парашутом, автомотоспорт, фристайл-акробатика та ін.);

- високі - контактні виАи спорту (вільна боротьба, греко-римська боротьба, рукопашний бій, традиційне карате, кікбоксинг, бокс, Азюдо, самбо), футбол, хокей із шайбою, важка атлетика, спортивна гімнастика, багатоборство, регбі, гірськолижний і лижний спорт та ін.;

- середні - ігрові види спорту (баскетбол, волейбол, гандбол, теніс, хокей на траві і т.А., крім футболу і хокею з шайбою), художня гімнастика, легка атлетика, стрільба з лука, стендова і кульова стрільба, фехтування, фігурне катання, віндсерфінг, вітрильний спорт, кінний спорт, акробатика, стрибки на батуті, ковзанярський спорт, санний спорт, велосипеАний спорт та ін.;

- низькі - плавання, водне поло, синхронне плавання, гольф, веслування, настільний теніс, спортивна аеробіка, бадмінтон, біатлон, городкового спорту та ін.

Строк чинності дії договору страхування може покривати події, що сталися:

1) цілодобово в період дії договору (наприклаА, протягом року);

2) у період заняття спортом, тренувань, навчально-тренувальних зборів, змагань;

3) у період проведення змагань.

Залежно віА рівня спортивної майстерності також виділяються окремі категорії, які враховуються піА час тарифікації страхування віА нещасних випаАків спортсменів, і медичне страхування спортсменів: 
1) спортсмени збірних комана (i їх резерву);

2) спортсмени шкіл вищої спортивної майстерності;

3) спортсмени вищих кмубних команА міста (області, землі, графства та ін.);

4) студенти вищих навчальних закладів фізичної культури;

5) учні Аитячо-юнацьких спортивних шкіл;

6) учні училищ фізкультури;

7) тренери [9].

Найбільш поширені варіантистрахування спортсменів віА нещасних випадків припускають виплату страхового віАшкодування, що компенсує збитки і втрату доходу в результаті травм і інших нещасних випадків, при цьому меАичні витрати покриваються за окремою програмою страхування.

Права та обов'язки за Аоговором страхування передбачається ст. 988, 989 ЦК України, конкретним договором та правилам страхування страхової компанії.

Загальні підстави відмови віА виплати страхової суми застрахованому передбачається ст. 991 ЦК України та конкретизуються в Аоговорі страхування.

Окрім Закону України "Про страхування" та Порядку, що містять вимогу укладення Аоговору обов'язкового державного страхування спортсменів вищих категорій, спеціальні правила проведення змагань окремих виАів спорту передбачають в якості умови Аопуску Аля участі у змаганнях положення про наявність Аоговору страхування. Такі положення передбачаються віАповіАно Ао Правил спортивних змагань із мижних гонок [10] Правил проведення змагань зі скелелазіння, Правил боксу Федерації боксу України [11] положенням клубу карате, тощо.

Професійний спорт $є$ комерційним напрямом Аіяльності у спорті, пов'язаним із піАготовкою та проведенням видовищних спортивних захоАів на високому організаційному рівні з метою отримання прибутку (ст. 38 Закону України «Про фізичну культуру і спорт»).

Аіяльність у професійному спорті спортсменів, тренерів та інших фахівців, яка полягає у піАготовці та участі у спортивних змаганнях сереА спортсменів-професіоналів, і є основним Ажерелом їхніх Аоходів, провадиться віАповідно Ао Закону України "Про фізичну культуру і спорт" та Кодексу законів про працю України та інших нормативно-правових актів, а також статутних та регламентних Аокументів віАповіАних суб'єктів сфери фізичної культури і спорту та міжнародних спортивних організацій.
Наразі спортсмен як професія в законодавстві не передбачається, а поняття "професійного спортсмену" законодавство України не містить. Спортсмен набуває статусу спортсмена-професіонала з моменту укиадення контракту 3 віАповіАними суб'єктами сфери фізичної культури і спорту про участь у змаганнях сереА спортсменів-професіоналів [12].

Міністерство молоді і спорту України, уклаАає трудовий договір (контракт) із спортсменами та фахівцями штатної команди національних збірних команд України з олімпійських, неолімпійських та національних виАів спорту, а 3 виАів спорту осіб з інвалідністю - Український центр з фізичної культури і спорту осіб з інвалідністю (ст. 37 Закону України «Про фізичну культуру і спорт»).

Органи державної влаАи сприяють розвитку матеріально-технічної бази національних спортивних федерацій осіб з інвалідністю або їх спілок, які $€$ членами Міжнародного паралімпійського комітету, Міжнародного спортивного комітету глухих, можуть надавати їм фінансову та організаційну Аопомогу Аля Аосягнення мети їхньої Аіяльності та на виконання статутних завдань, пов'язаних із розвитком паралімпійського і дефлімпійського руху в Україні.

Визнання спортсменів представниками конкретної професії має значити включення їх Ао програми обов'язкового соціального страхування віА нещасних випадків і професійних захворювань та поширення Аії Закону України «Про загальнообов'язкове Аержавне соціальне страхування" про гарантії працюючих громадян щодо їх соціального захисту у зв'язку з тимчасовою втратою працездатності, вагітністю та пологами, віА нещасного випадку на виробництві та професійного захворювання, охорони життя та зАоров'я [13].

Як свідчить практика, спортсменам отримати віАшкодування віАповіАно до положень зазначеного Закону складно та супроводжено тривалою судовою тяганиною, що зумовлено специфічністю трудової Аіяльності та невизначеність статусу спортсмена у законодавстві [3].

Ураховуючи викладене, сліА констатувати, що на соціальний захист спортсменів, отримання віАшкодування у зв'язку з тимчасовою втратою працездатності, настанням нещасного випадку, перериванням Аіяльності через вагітність та пологи впливають такі чинники як: категорія спортсмену, можливість застосуванням обов'язкової або Аобровільної форми страхування та недостатня визначеність правового статусу спортсменів у чинному законодавстві. 


\section{NITEPATYPA:}

1. Розина И.П. Обязательное и добровольное страхование спортсменов. URL : http://iais.kemsu.ru/conf_web1/GetDocsFile?id $=49997 \&$ table $=$ papers_file\&type...

2. Суха Ю.С. Деякі питання правового регулювання відносин страхування у професійному спорті. Науковий вісник Ужгородського національного університету. 2013. № 21. С. 275-279.

3. Тіхонова М.А. Види страхування у сфері фізичної культури і спорту. Право і безпека. 2011. № 1(38). С. $234-239$.

4. Клименко М. Самые интересные факты и случаи в страховке [46 случаев]. URL : https://avtomaniya.com/site/publicationfull/ 689 .

5. Про фізичну культуру і спорт Закон України. Відомості Верховної Ради Украӥни. 1994. № 14. ст. 80.

6. Порядок та умов обов'язкового державного страхування спортсменів вищих категорій: постанова Кабінету Міністрів України від 31 травня 1995 № 378. URL : http://zakon.rada.gov.ua/cgi-bin/laws/main.cgi?nreg=378-95-\%EF.

7. Токарева В.О. Правовідносини страхування творів мистецтва, предметів колекціонування та антикваріату : монографія. 2012. C. 80 .

8. Про підтримку олімпійського і параолімпійського руху та спорту вищих досягнень в України : Закон України від 14 вересня 2000 № 1954-ІІІ. Відомості Верховної Ради. 2000. № 43. Ст. 370.

9. Цыганов А.А. Зарубежная практика страхования спортсменов. Организация продаж страховых продуктов. 2007 . № 6. С. 7.

10. Правила спортивних змагань з лижних гонок. URL : http://www.sfu.org.ua/official_documents/ukrainian_rules/ukr_rules_ cross-country.

11. Правил боксу Федерації боксу України. URL : http://www.newstars.com.ua/123/130.

12. Про обов'язкове страхування спортсменів для участі у турнірах УФК! URL.: http://progresskarate.com.

13. Полянський А.О. Правові проблеми регулювання праці професійних спортсменів в Україні. Збірник наукових праць Харківського національного педагогічного університету імені Г.С. Сковороди «ПРАВО». 2011. № 16. С. 47-53.

14. Про загальнообов’язкове державне соціальне страхування: Закон України від 23 вересня 1999 № 1105-XIV. Bidoмості Bepховної Ради України. 1999. № 46. Ст. 403.

\section{Токарева Віра Олександрівна}

\section{ПРАВОВЕ РЕГУАЮВАННЯ СТРАХУВАННЯ СПОРТСМЕНІВ}

Стаття присвячена окремим питанням правового регулювання страхування спортсменів. Встановлено, що: страхування спортсменів віА нещасних випадків є одним із різновидів страхування, поряд із страхуванням особистого майна спортсменів, інвентарю та обладнання команд, цивільною віАповіАальністю організаторів спортивних змагань, учасників спортивних правовідносин (гравців, судАів, тренерів, вболівальників тощо) перед третіми особами на випадок смерті, каліцтва чи іншого ушкодження зАоров'я та страхування на випадок скасування, відстрочення, перенесення спортивних заходів з причин, що не залежать віА учасників та організаторів змагань.

3'ясовано, що дослідження страхування в галузі спорту має провадитись з урахуванням його поділу на спорт на аматорський або непрофесійний та професійний спорт, піА яким сліА розуміти комерційний напрямок Аіяльності у спорті, пов'язаний з підготовкою та проведенням видовищних спортивних заходів на високому організаційному рівні з метою отримання прибутку.

3'ясовано, що спортсмени вищих категорій піАлягають обов'язковому страхуванню віАповідно Ао чинного законодавства України. Надана характеристика та встановлені особливості правового статусу страхувальника, страховика та застрахованого в договорах обов'язкового страхування спортсменів віщих категорій.

Проаналізовані випадки, віА настання яких провадиться страхування. Визначені групи ризиків залежно віА виду спорту, небезпечності травм та ймовірності настання випаАку та їх вплив на розмір страхового тарифу в разі страхування.

3'ясовано, що страхування в галузі спорту може провадиться з метою реклами та піару компанії.

Киючові слова: страхування, обов'язкове страхування, обов'язкове страхування спортсменів, страхування спортсменів вищих категорій, професійний спорт.

\section{Tokareva Vira}

\section{LEGAL REGULATION OF SPORTS PERSONAL ACCIDENTS INSURANCE}

The article is devoted to certain issues of legal regulation of sports insurance. Statistics of occupational diseases and injuries among athletes aren't kept, which makes it difficult difficulties to determine the number of athletes who received insurance benefits and what cases occur most often

It is established that: the sports personal accidents insurance, is one of the types of sports insurance, along with insurance of property of athletes, teams inventory and equipment, civil liability of organizers of sports competitions, participants of sports relations (players, judges, fans, etc.) to third parties in case of death, injury, other damage to health and insurance of cancellation, postponement of sporting events for reasons beyond the control of participants and organizers of competitions.

The study of sports insurance was found to be conducted taking into account its division of amateur or nonprofessional and professional sports, which should be understood as a commercial activity in sports related to the preparation and conduct of spectacular sporting events at a high organizational level for revenue profit. 
The athletes of higher categories was considered to be a subject to compulsory insurance in accordance with current Ukrainian legislation.

The characteristics and features of the legal status of the insurer and the insured in the contracts of compulsory sports personal accidents insurance of the higher categories athletes are given.

The cases from the occurrence of which insurance is provided are analyzed. Determining the group of risks depending on the sport, the risk of injury and the probability of an accident and their impact on the size of the insurance rate in the case of insurance.

It has been found that insurance in the field of sports can be provided for the purpose of advertising and PR of the company.

Key words: insurance, compulsory insurance, sport insurance, sports personal accidents insurance, insurance of athletes, professional sports. 